\title{
The Real Estate Impact of Recreational Areas on the Residential Property Values in Riyadh, Saudi Arabia
}

\author{
Faisal A. Alawwad ${ }^{1}$, Waleed S. Alzamil ${ }^{2}$ \\ ${ }^{1}$ Master of Real Estate Development, Department of Urban Planning, King Saud University, Riyadh, Kingdom of Saudi \\ Arabia \\ ${ }^{2}$ Associate Professor, Department of Urban Planning, King Saud University, Riyadh, Kingdom of Saudi Arabia
}

Correspondence: Waleed S. Alzamil, E-mail: waalzamil@ksu.edu.sa; Faisal A. Alawwad, E-mail: faisal.alawwad89@gmail.com

Received: October 10, 2019

doi:10.11114/ijsss.v8i1.4627

Accepted: November 11, $2019 \quad$ Available online: November 27, 2019

URL: https://doi.org/10.11114/ijsss.v8i1.4627

\begin{abstract}
Recreational areas are one of the most important uses in the modern residential neighborhoods because they improve economic resources, social life, and environmental quality. This paper discusses the impact of recreational areas on residential property values in Riyadh. The paper relies on the descriptive and comparative analysis of the case study model 'Al-Hokair Land' by extrapolating the residents' view of the residential properties close to the recreational area in Al-Hamra neighborhood. The paper also analyzed the relationship between recreational area and land price changes in urban communities within Al-Hamra district. The paper found that the average land price in Al-Hamra district is $\$ 826$ per square meter, which is the highest compared to the neighboring areas. Moreover, land prices in urban communities near the recreational area are the highest with an average of $\$ 933$ per square meter. Finally, the value of residential properties areas is affected by environmental, security, urban or social factors associated with recreational activity. Therefore, the paper recommends improving the quality of the urban environment to ensure the stability of the residential properties value in line within framework of the Saudi Vision 2030.
\end{abstract}

Keywords: impact, real estate, recreational areas, residential, property, values, Riyadh, Saudi Arabia

\section{Introduction}

Saudi Arabia has witnessed economic growth over the past decades, with rapid urbanization in major cities (Alzamil, 2016). The National Urban Strategy 2030 adopts an approach in which urban areas and major cities are gates to the world. Major projects will also be the engine for the urban, social and economic development that is associated with the opening up of the national economy to the world (MOMRA, 2018). The King Salman Park is the first ambitious leisure projects announced in 2019 covers an area of 13.3 square kilometers. The project aims to create a dynamic transformation in the urban style of Riyadh, instead of the current situation where vehicles are the main means of transport. This Future change will positively affect Saudi Arabia's economic diversification, support the cultural and leisure activities sector, expand the tourism sector and employ modern technology (MOMRA, 2018).

Saudi Vision 2030 has set three pillars for building a vibrant society, a thriving economy, and an ambitious homeland (Vision of the Kingdom 2030, 2016). This Vision provided a number of goals and initiatives to enhance the livelihoods and quality of life of the population including Vision 6: Quality of Life Improvement Program. This program seeks to improve the lifestyle of the individual and the family to build a society with a balanced lifestyle by improving the environment and creating new options that promote participation in cultural, recreational and sports activities (National Transformation Program, 2018). In this context, Vision 2030 focused on three main principles in the development of the residential environment: first, to enhance household's ownership by providing a large number of high-quality housing units that are compatible with the financial income. Second, to promote sustainability of residential environment by increasing the green areas and providing a health system for the residents of the neighborhood. Third, developing the non-profit sector for housing by supporting low incomes families (Bahamam, 2018).

Residential neighborhoods should contribute to the creation of a sustainable, high-quality urban environment within the household economic capacity. However, there are many factors affecting the value of residential properties such as supply, demand, availability of services, and the current economic situation (Al-Otaibi \& Alzamil, 2019). The Tenth 
Development Plan aims to achieve a national economy with highly competitive capabilities based on upgrading continuous productivity and improved product quality. Therefore, the development plan focuses on qualitative development of the national workforce, raising investment rates, and expanding the use of advanced production techniques and modern management methods (Ministry of Economy and Planning, 2015, p. 46). At present, the entertainment sector is one of the most important investment sectors that have expanded in Saudi Arabia. It is expected that this sector will contribute to achieving the objectives of Vision 2030 to increase the assets of the Public Investment Fund and multiplicity of wealth sources, and income. Saudi Public Investment Fund (PIF) has initiated the establishment of investment company with a capital of $\$ 2.6$ billion to operate parks and recreational activities in Saudi Arabia (Public Investment Fund Program, 2018). Typically, recreational activity is accompanied by many effects on surrounding areas Including economic, social, environmental and urban dimensions.

This paper highlights the real estate impact of recreational areas on the residential properties in Riyadh. As shown in Fig. 1: The paper used a case study model 'Al-Hokair Land' in Al-Hamra neighborhood to analyze the impact of recreational activity on residential properties values. The analysis is based on monitoring and comparing the change in land prices in urban communities within Al-Hamra district. In addition, analysis of the current situation involves extrapolating the views of (50) residents in Al-Hamra neighborhood about recreational area of 'Al-Hokair Land'. The sample of questionnaire is 50 residents in Al-Hamra district and it has been selected randomly after dividing the district into four main zones each zone has the same percentage $25 \%$. The paper summarizes the most important factors affecting the value of residential properties close to recreational areas based on the residents' perspective.

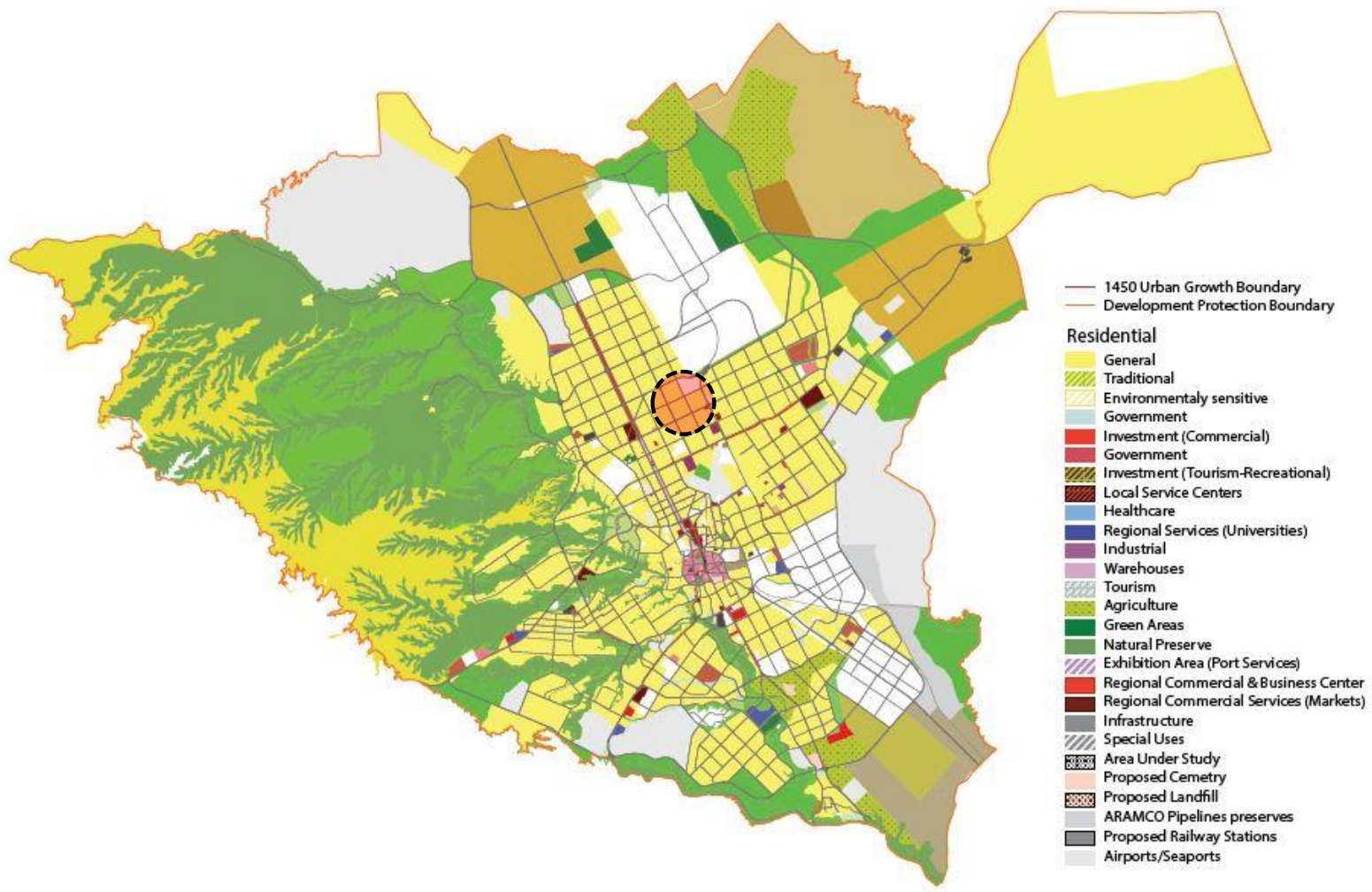

Figure 1. Site of the case study within the land use scheme Riyadh

Source: (MOMRA, 2017, p. 75).

\section{Research Problem}

Saudi Arabia is witnessing a major boom in the entertainment sector, which has started to establish the Public Entertainment Authority. The Public Investment Fund has also set up a private entertainment company to oversee and operate entertainment projects in Saudi Arabia. in 2020, Saudi Arabia is seeking to increase recreational complexes and activities in Riyadh from 110 to 141 recreational activities (National Transformation Program, 2018). The proliferation of recreational projects within the residential area has many effects on surrounding residential properties. Therefore, there is a need to analyze the real estate impact of recreational areas on adjacent properties in order to control the factors that play a role in the value of residential properties. 


\section{Research Objective}

This paper aims to analyze the real estate impact of recreational areas on the value of residential properties in Riyadh. This helps to control the negative effects and enhance the quality of life in residential neighborhoods within Saudi Vision 2030.

\section{Methodology}

This paper adopts descriptive and comparative analysis of case study in Al-Hamra neighborhood in Riyadh. The case study was chosen because it is a residential area with a huge entertainment component. The analysis examines the relationship between recreational area 'Al-Hokair Land' and neighboring residential properties. Descriptive analysis helps to answer the question: What is the real estate impact of recreational areas on residential properties values? Comparative analysis helps answer the question: What are the differences in land prices between Al-Hamra and adjacent areas? Moreover, the analysis relies on a reviewing of Ministry of Justice reports and real estate offices that address the value of residential properties in the neighborhood during the last 5 years. Secondary data were prepared by reviewing the reports of a number of ministries and government agencies such as: Ministry of Housing, General Organization for Statistics, General Investment Authority, and Ar-Riyadh Development Authority (ADA). Primary data was collected based on field survey, observation, and investigation with residents. Questionnaires were distributed to (50) residents in four residential communities that close to the recreational area within 'Al-Hamra' neighborhood in Riyadh. As shown in Fig. 2: Samples were distributed in the entire residential neighborhood by $25 \%$ per community. Finally, statistical Package for the Social Sciences (SPSS 17.00) used to measure residents' views and compare them with government statistics on residential land value.

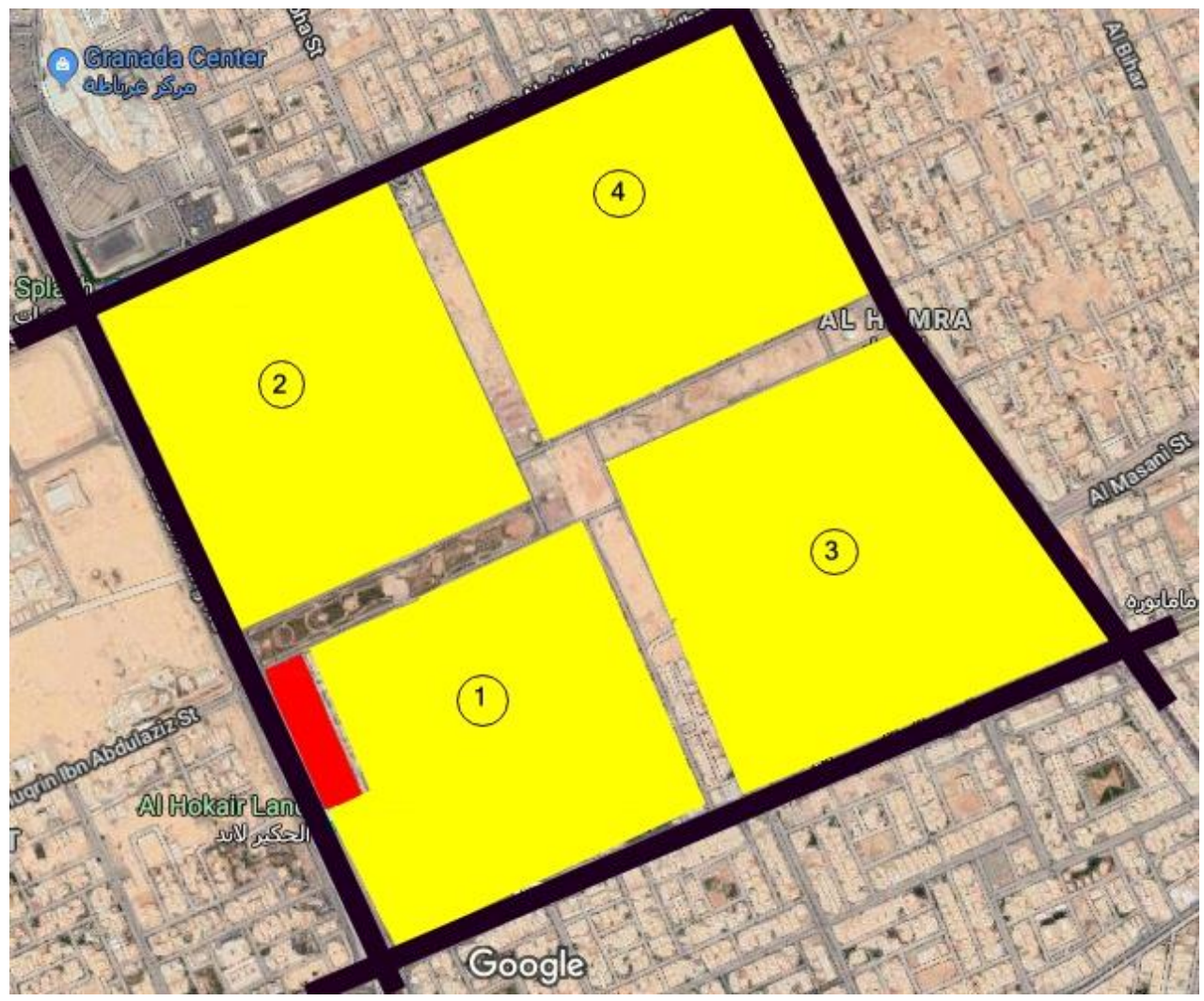

Figure 2. Location of residential communities within 'Al Hamra' neighborhood in Riyadh

Source: Authors based on Google Maps.

\subsection{Data Collection}

Table 1. shows the data collection that used on this paper to helps answering the question: what is the real estate impact of recreational area on residential properties values? 
Table 1. Study variables and data collection mechanisms

\begin{tabular}{|c|c|c|}
\hline Study variables & Data Mechanism & Source \\
\hline $\begin{array}{l}\text { Villas and land purchase prices from } 2012 \text { to } \\
2018\end{array}$ & Government statistics - Market survey & $\begin{array}{c}\text { Ministry of Justice - Real estate } \\
\text { agent }\end{array}$ \\
\hline Villa and land rental prices on the current year & Government statistics - Market survey & $\begin{array}{c}\text { Ministry of Justice - Real estate } \\
\text { agent }\end{array}$ \\
\hline Land and assets sales from 2012 to 2018 & Government statistics - Field survey & $\begin{array}{c}\text { Ministry of Justice - Real estate } \\
\text { agent }\end{array}$ \\
\hline $\begin{array}{c}\text { Vacant land values on Al-Hamra and the } \\
\text { surrounding districts }\end{array}$ & Field survey & $\begin{array}{l}\text { Real estate agent - Field survey } \\
\text { from the authors }\end{array}$ \\
\hline $\begin{array}{l}\text { Saudi and expat families within the Al-Hamra } \\
\text { districts }\end{array}$ & Field survey & Field survey from the authors \\
\hline Residence family income & Field survey & Field survey from the authors \\
\hline Residence average age & Field survey & Field survey from the authors \\
\hline Residence family member & Field survey & Field survey from the authors \\
\hline $\begin{array}{l}\text { Land use and regulations for the surrounding } \\
\text { area of case study }\end{array}$ & Government data & $\begin{array}{c}\text { Ministry of Municipal and Rural } \\
\text { Affairs }\end{array}$ \\
\hline Building permit regulations for the case study & Government data & $\begin{array}{c}\text { Ministry of Municipal and Rural } \\
\text { Affairs }\end{array}$ \\
\hline $\begin{array}{c}\text { Spending average per capita for entertainment in } \\
\text { Riyadh }\end{array}$ & Government data & General Authority for Statistics \\
\hline Entertainment market size for Riyadh & Government data & General Authority for Statistics \\
\hline Operational regulation for case study & Government data & General Authority for Statistics \\
\hline
\end{tabular}

\subsection{Data Analysis}

There is two method that been used on this paper 1. Descriptive approach Causal, 2. Descriptive survey method. Descriptive approach used to study the impact of recreational area on residential properties values through reviewing the previous studies and references either direct or indirect approach with comparable case studies. Descriptive survey method used to understand the impact of the recreational areas by understanding resident's satisfaction. in addition, analyzing current values of assets and lands on the district by investigating with the real estate agents. Questionnaires were distributed to 50 residence measures five aspects that answer the main question which is the impact of recreational area on residential properties values, the first aspect is about the residence information in terms of ages, family members, career, family income and family nationality. The second aspect is about the security impact for the case study on the value of real estate such as the traffic impact of the case study and its security on the community, and pedestrian impact. The third aspect is environmental impact of the case study on the community including infrastructural, noise, and light pollution. The fourth aspect is the social impact for the residence community which defined by how the case study was help to gathering the surrounding community and it improve the connection between the residences.

\section{Literature Review}

\subsection{Effectiveness of Residential Properties Values}

There are many factors that affect the value of residential properties such as spatial distribution, property management, and real estate market (Al-Otaibi \& Alzamil, 2019). As shown in Fig. 3: There are constant variables factors affecting for residential properties include population growth, urban expansion, per capita income, construction costs, and taxes. Other factors that affect the values of residential properties are the variables factors it depends on the location, ethnic aspect for the surrounding districts, property age and size.(Al-Qaadi, Al-Jarallah, \& Al-Diwifi, 2004). 


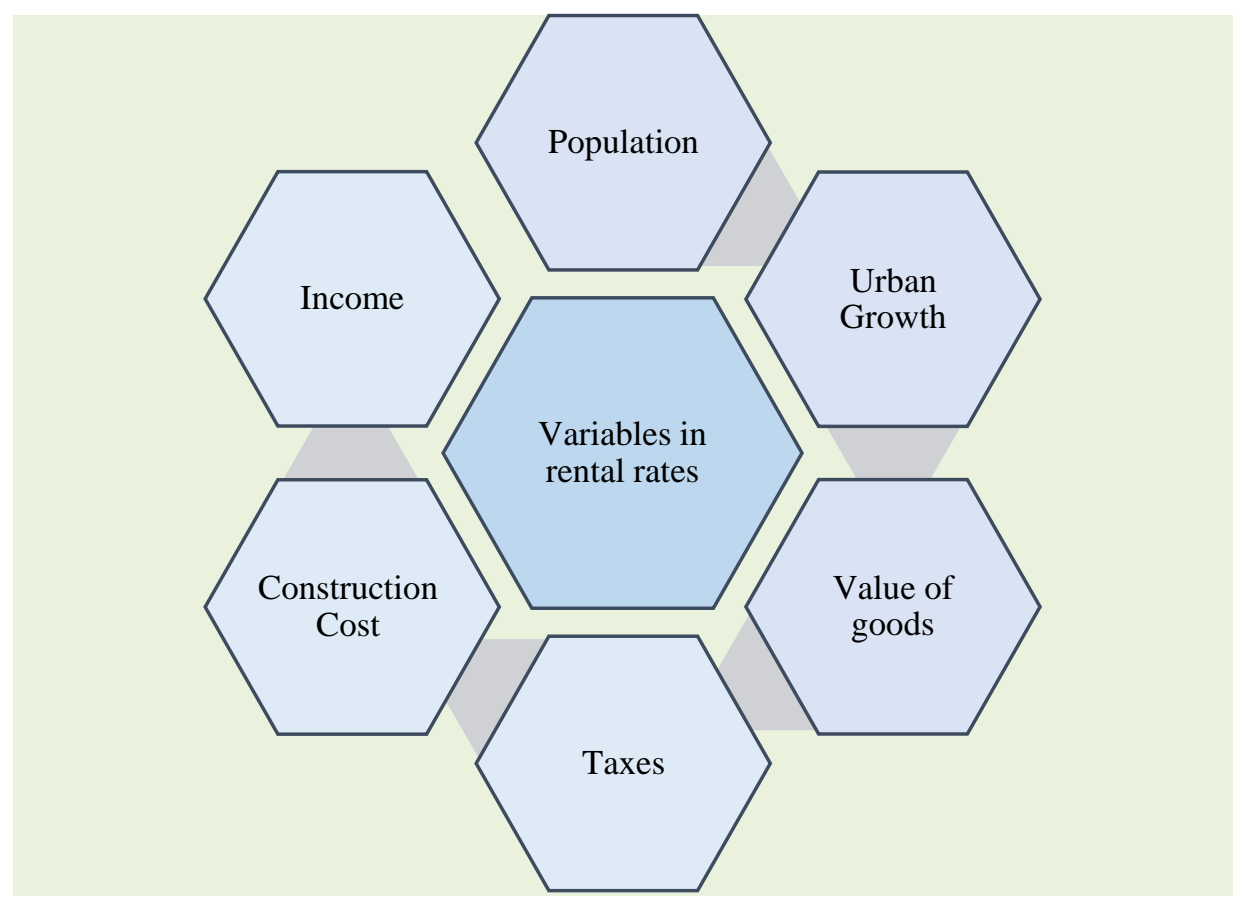

Figure 3. Constant variables factors affecting for residential properties

Sources: (Al-Qaadi, Al-Jarallah, \& Al-Diwifi, 2004).

\subsection{The Concept of Recreation}

Recreation areas are urban spaces that including entertainment activities. This term refers to an activity that consumers often spend outside the home for pleasure and satisfaction (Pigram, 1983). Therefore, recreational areas generate many tangible effects such as traffic congestion, noise, and emissions. Recreational areas are one of the most important land uses in the city, which contribute to psychological regeneration, improving quality of life, and revitalization of residents (Mitković \& Bogdanović, 2004). Moreover, these areas provide an opportunity for people to meet others, compete sports, and promote physical, mental health, cognitive and cultural benefits (King County's Open Space System, 2004).

\subsection{The Impact of Recreational Areas on Property Values}

Urban sprawl has affected the natural environment in many cities, where the size of open areas has decreased at the expense of urban blocks. The recreational area is an important tool for economic growth because it increases the value of neighboring properties, demand and employment. The property market indicates that many residents prefer to stay near parks or open areas. Crompton (2017) describes that residents are often willing to pay more for residential properties that are located near a recreational area than they are for a similar one that located away. Therefore, the prices of land adjacent to those areas remain higher than the rest of the land in the neighborhood (Aliyu, Bello, AdamuI, \& Musa, 2016). Espey \& Owusu-Edusei (2001) estimated the impact of the parks on the prices of neighboring properties based on the distance and park type in Greenville. Recreation areas contribute to the improvement of the urban environment. Therefore, these areas have a positive impact on the value of neighboring properties. Parks can increase $20 \%$ of the value of nearby houses up to approximately 600 feet. Community gardens may increase the value of residential real estate to $33 \%$. This effect is possible to reach real estate that is located 1000 to 2000 feet from the large community park to achieve a 9\% increase in home value (Aliyu, Bello, AdamuI, \& Musa, 2016). Anderson (2001) found that the proximity to recreational areas varies by type of entertainment activity, neighborhood characteristics, and urban scale. Proximity to parks has positive impact of $\$ 354$ per 100 meters in the city and a negative impact of $\$ 252$ per 100 meters in the suburbs. In addition, proximity to golf areas has a positive impact of $\$ 395$ per 100 meters in the city and $\$ 49$ per 100 meters suburbs. Bolitzer \& Netusil (2000) argues that recreation areas such as public parks, natural areas and playgrounds may have an impact on the value of residential properties adjacent to them. However, the net effect of proximity to recreational areas is uncertain due to negative external factors such as traffic congestion and noise. Recreational areas that are inappropriate for the community or poorly maintained will not have a significant positive impact. Moreover, these areas can increase traffic and noise (Espey \& Owusu-Edusei, 2001). The positive effects of recreational areas on residential properties can be observed depending on the quality of facilities, maintenance, 
management, and marketing methods (Hailegiorgis, 2017).

\subsection{The Impact of Recreational Areas in the Urban Context}

Recreational areas often revitalize surrounding areas by providing services, jobs, suburban planning, and attracting investments. Therefore, many entertainment companies purchase land around entertainment cities for the purpose of future expansion or to control of land prices and the type of land use around these areas (Clave, 2007). Recreational areas affect the type of land use in residential areas, which leads to the emergence of patterns of uses that integrated with recreational area such as hotels, shopping centers, and tourism activities. As shown in Fig. 4: The green areas surrounding Disneyland were 72\% in 1955 (384 ha). However, the proportion of green areas decreased in 1990 to 12\% (Clave, 2007).

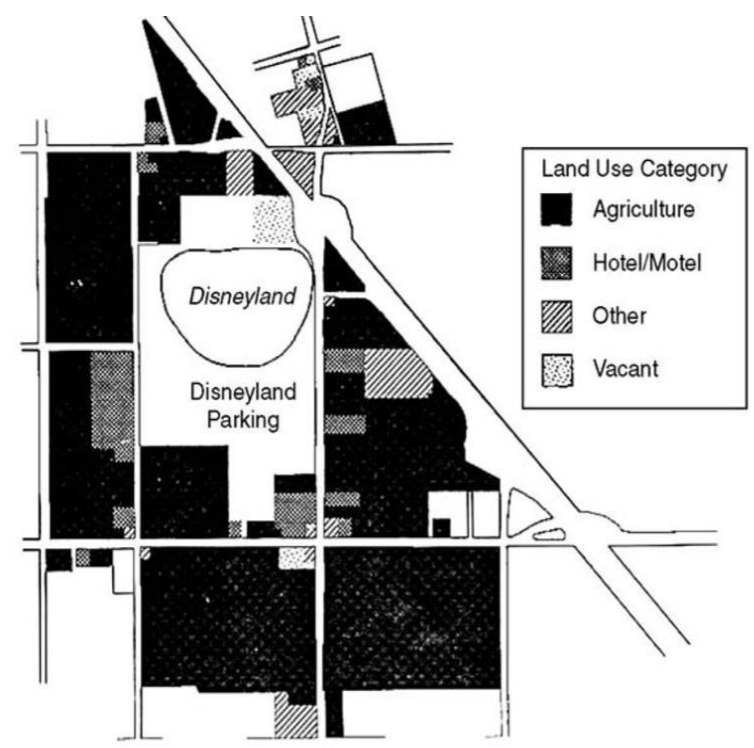

The area surrounding Disneyland in 1955

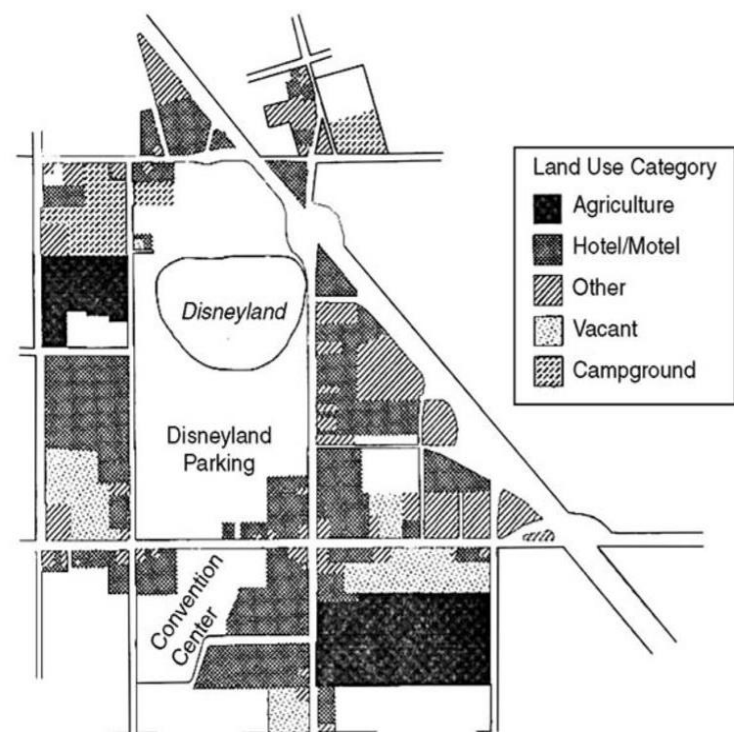

The area surrounding Disneyland in 1990

Figure 4. The impact of recreational activity on land uses

Source: (Clave, 2007).

\section{Result}

As shown in the Fig. 5: The case study of 'Al-Hokair Land' is located in Al-Hamra district, along a commercial axis northeast of Riyadh. The cause of choosing the case study is the characteristics of the site location that it's within a residential district. The scope of the impact of the recreational area extends to four residential communities. As shown in Fig. 6: The site can be accessed through the main roads such as King Abdullah Road and the Eastern Ring. 


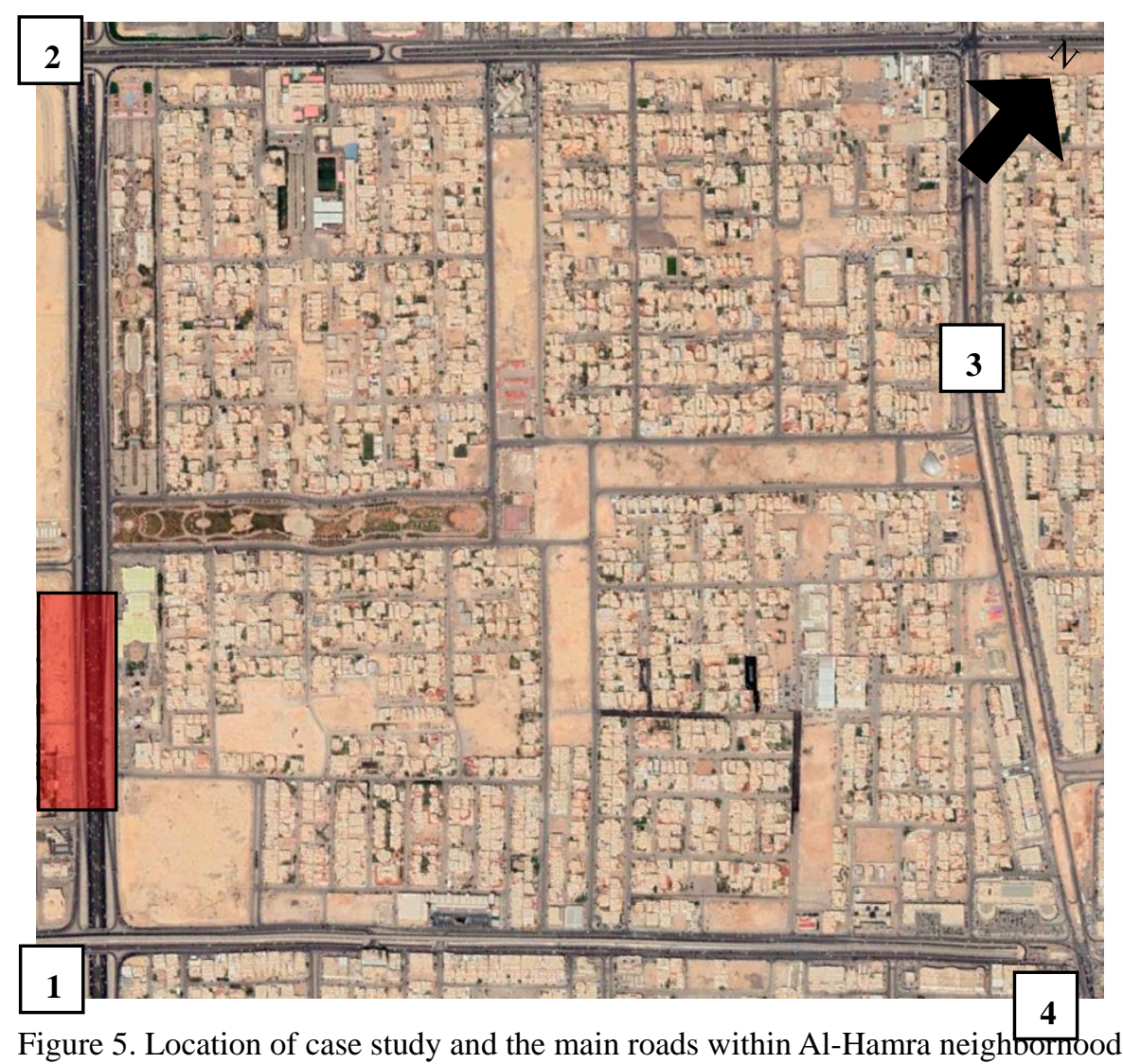

Source: Authors based on Google Maps.
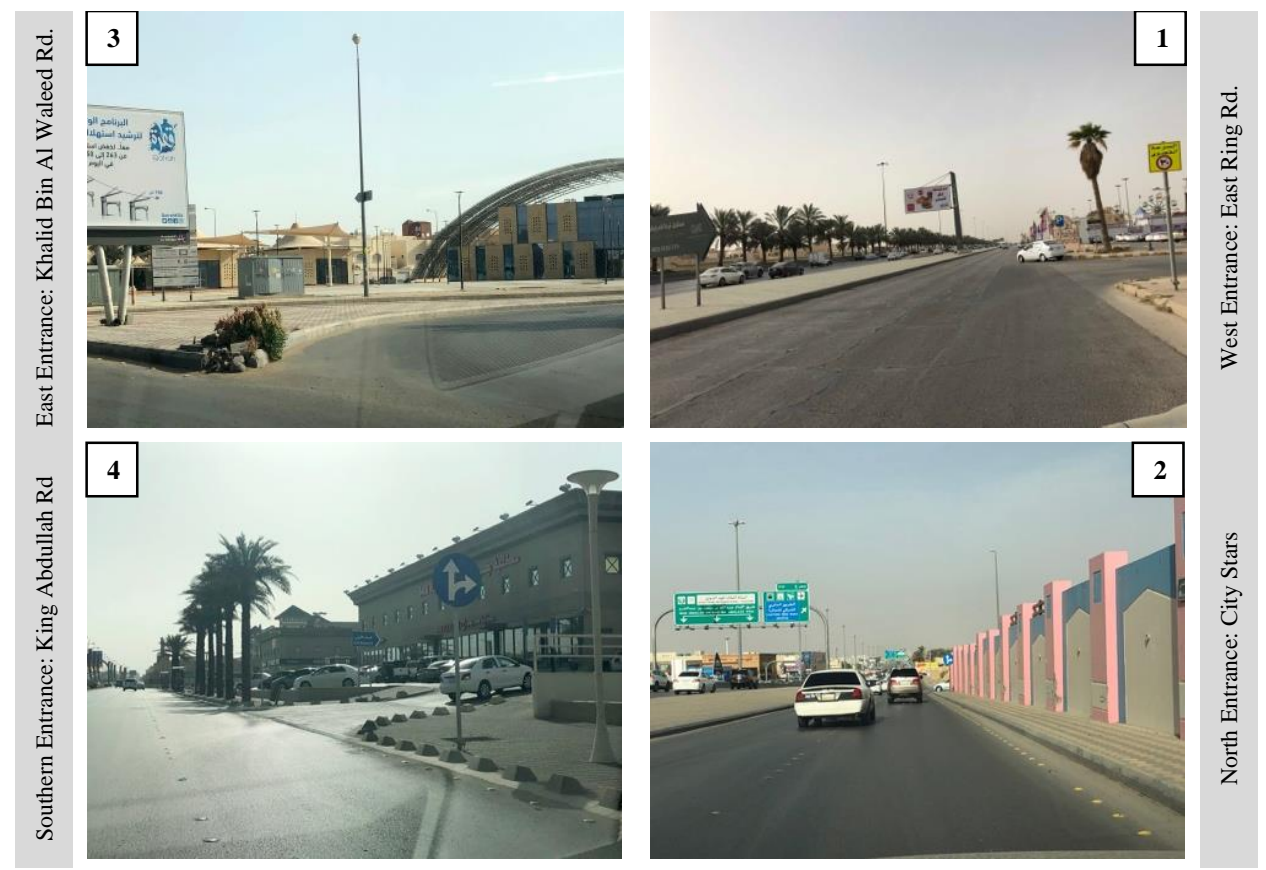

Figure 6. Roads and main entrances to case study of 'Al-Hokair Land'

Source: Authors. 
According to the statistics of the Ministry of Justice on land prices in Al-Hamra district over the past 8 years, there has been a slight drop in land prices. As shown in Fig. 7: The average value per square meter was $\$ 1040$ in 2010 . The lowest value per square meter was $\$ 826$ in 2017. Statistical analysis indicates that the average price of land over the past 8 years is $\$ 963$. However, there is a difference in the average price of villas as the highest value of villa area of 600 square meters is $\$ 613,375$ in 2015. Fig.8: Illustrated that the average price of villa reached \$400,027 in 2017 and 2018 respectively. Depending on the statistics of the Ministry of Justice, the average price of the villa in Al-Hamra district from 2010 until 2018 is $\$ 468,180$.

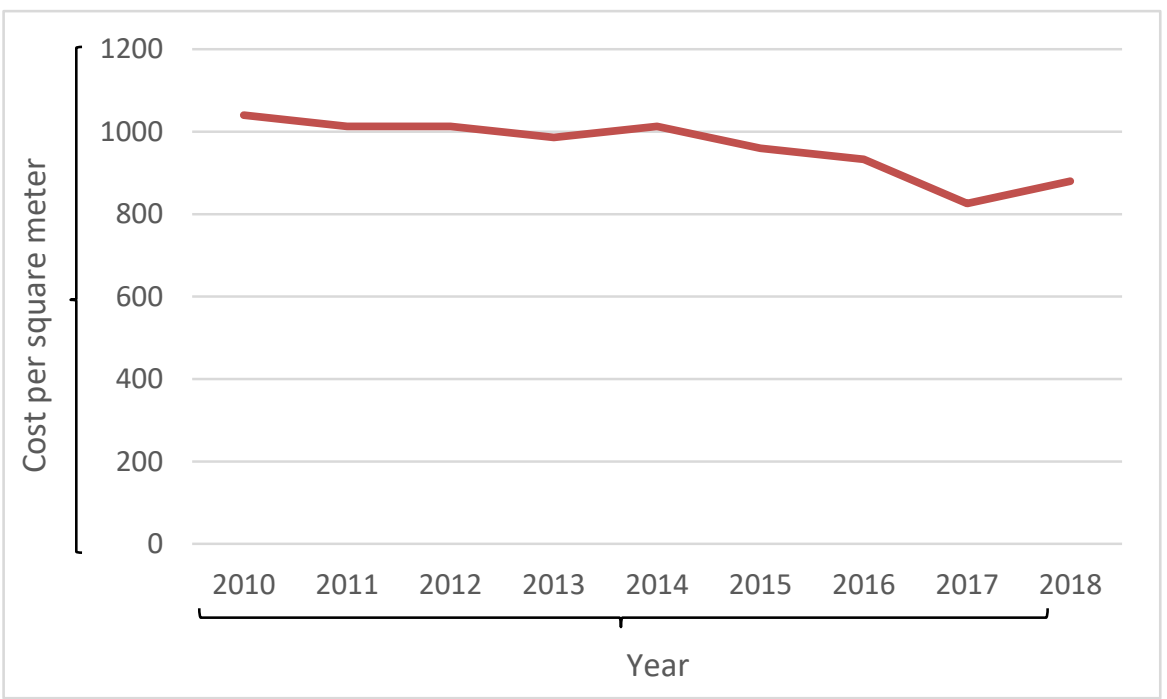

Figure 7. Price per square meter of residential land

Price were converted from Saudi Riyal to US Dollar.

Source: (Ministry of Justice, 2019).

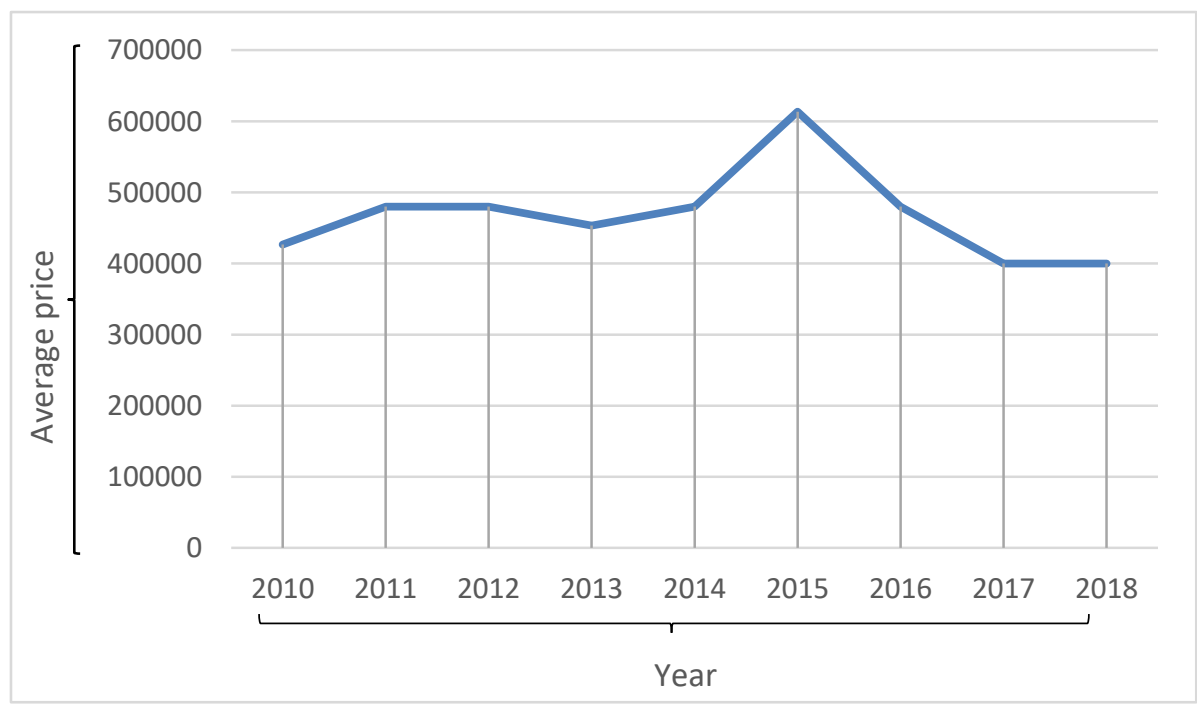

Figure 8. Average price of villa (600 square meters)

Price were converted from Saudi Riyal to US Dollar.

Source: (Ministry of Justice, 2019).

The results of the comparative analysis of land prices in the show that there is a drop in the prices of land adjacent to the Al-Hamra neighborhood between 10\%-39\%. Table 2 shows that the average land price per square meter in the Al-Hamra Eastern district is $\$ 573$ which is $30 \%$ lower than the average land price in Al-Hamra district. However, the average land price per square meter in Al-Quds is \$506 which is 39\% lower than the average land price in Al-Hamra district. Real 
estate developers pointed out that the presence of the recreational area positively affected the value of residential properties in Al-Hamra district. Fig. 9: shows that the spatial distribution of land prices in the Hamra district is the highest compared to the adjacent areas. Al-Saad (2014) believes that the real estate adjacent to recreational areas may be economically affected. This effect has been positively observed in Al-Hamra comparing with adjacent areas.

Table 2. Residential land price in Al-Hamra and adjacent neighborhoods

\begin{tabular}{ccccc}
\hline Neighborhoods & Lowest price $/ \mathrm{m}^{2}$ & Highest price/ $\mathrm{m}^{2}$ & Average & Rate \\
\hline Al-Hamra & 720 & 933 & 826 & $0 \%$ \\
Al-Hamra Eastern & 506 & 640 & 573 & $-30 \%$ \\
Al-Quds & 480 & 533 & 506 & $-39 \%$ \\
Mugharazat & 613 & 693 & 653 & $-21 \%$ \\
Granada & 533 & 666 & 599 & $-27 \%$ \\
\hline
\end{tabular}

Price were converted from Saudi Riyal to US Dollar.

Source: (Ministry of Justice, 2019); Ahmed Al Muzaini Office, Raka'z Al Hamra Office, Al Nabajah Office, Abdullah Al Habib Office and Al Salama Real Estate Office

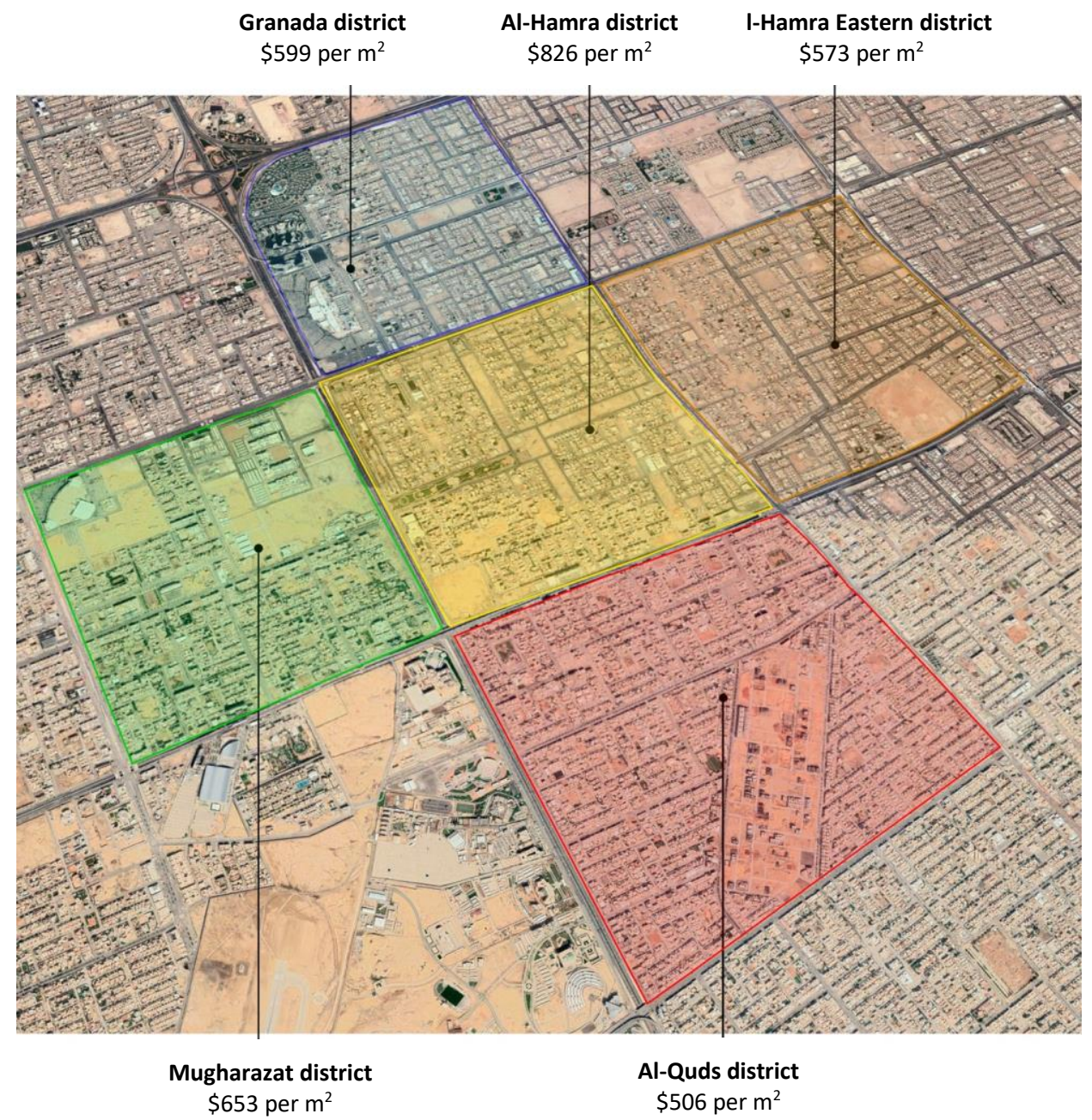

Figure 9. Spatial distribution of land prices in $\mathrm{Al}$ - Hamra and adjacent neighborhoods

Price were converted from Saudi Riyal to US Dollar.

Source: (Ministry of Justice, 2019); Ahmed Al Muzaini Office, Raka'z Al Hamra Office, Al Nabajah Office, Abdullah Al Habib Office and Al Salama Real Estate Office 
Figure 10: shows a spatial analysis of land prices in Al Hamra district within four residential communities. Community No. 1 represents the closest to the recreational area and has an average land price of $\$ 933$ per square meter. Moreover, community No. 2 has an average land price of $\$ 853$ per square meter. The rest of the residential communities have a significantly lower land price ranging from $\$ 720$ to $\$ 773$. The results of the analysis show that land prices decreased by $9 \%$ - $23 \%$ in communities located far from the recreational area. More than $68 \%$ of respondents confirm that the recreational area can strengthen social relations between residents, thus raising the value of neighboring properties. In fact, there are many factors that play a role in the prices of residential properties adjacent to recreational areas. Table 3 summarizes the views of residents about the real estate impact of recreational areas on the residential properties in Al-Hamra neighborhood. Respondents cited four factors that could affect residential property including security, environmental, social, and urban dimensions. For instance, more than $60 \%$ of respondents indicated believe that security factors arising from frequent traffic and traffic can negatively affect the prices of neighboring properties. In general, the real estate impact of recreational areas on residential properties varies depending on the ability to control the security, environmental, social, and urban factors of recreational area.

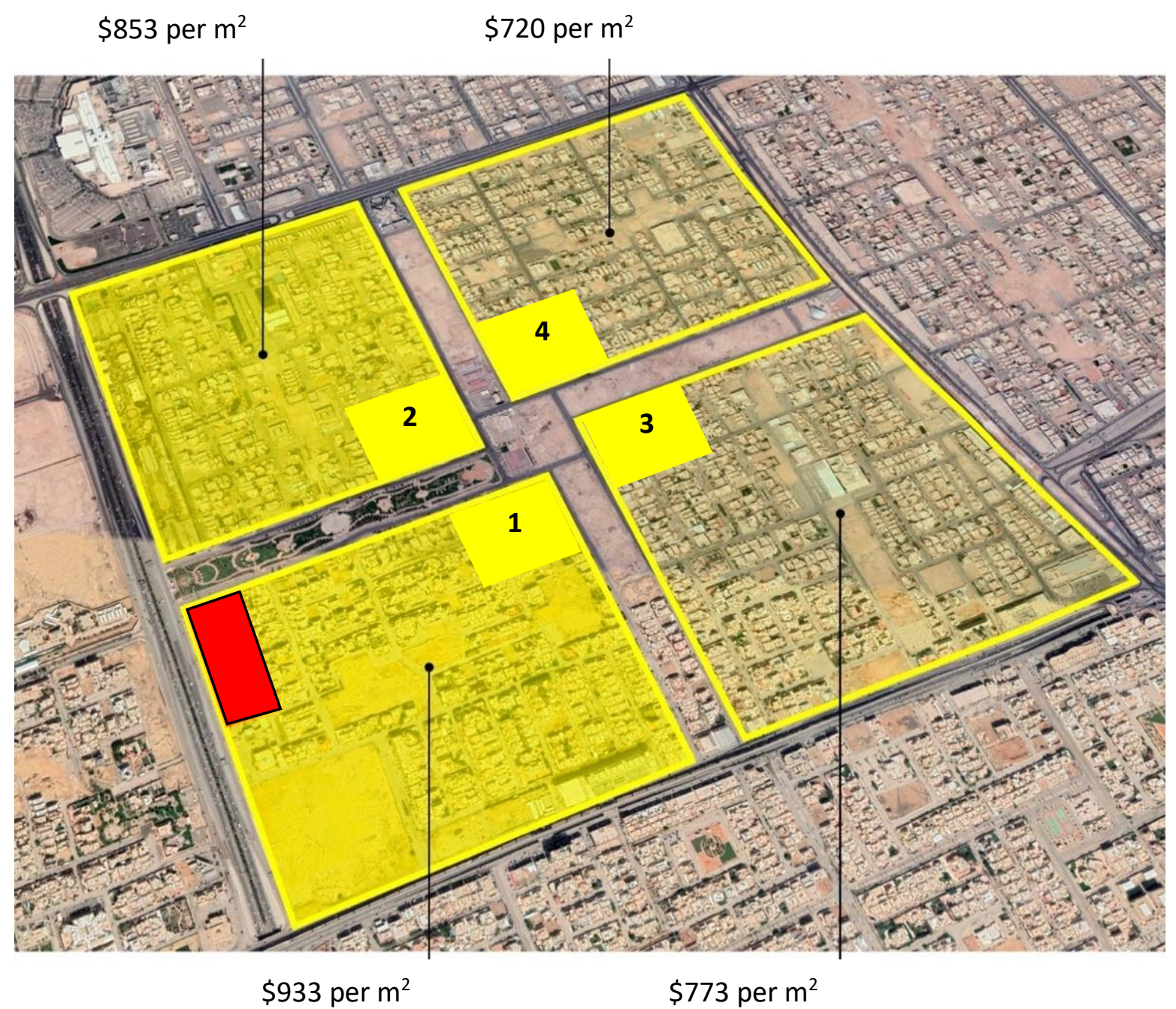

Figure 10. Spatial distribution of land prices in $\mathrm{Al}$ - Hamra (4 residential communities)

Price were converted from Saudi Riyal to US Dollar.

Source: (Ministry of Justice, 2019); Ahmed Al Muzaini Office, Raka'z Al Hamra Office, Al Nabajah Office, Abdullah Al Habib Office and Al Salama Real Estate Office 
Table 3. The real estate impact of recreational areas on the residential properties

\begin{tabular}{|c|c|c|c|c|c|c|c|}
\hline \multirow{6}{*}{ 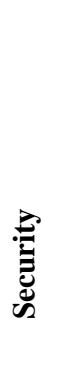 } & \multirow[t]{2}{*}{ impact factors } & \multicolumn{6}{|c|}{ Percentage of respondents } \\
\hline & & Frequency & $\begin{array}{l}\text { Strongly } \\
\text { agree }\end{array}$ & Agree & Neutral & $\begin{array}{l}\text { Not } \\
\text { agree }\end{array}$ & $\begin{array}{l}\text { Strongly } \\
\text { Disagree }\end{array}$ \\
\hline & Traffic resulting from the recreational area can & No. & 5 & 34 & 2 & 7 & 2 \\
\hline & cause security incidents & Perc. & 10 & 68 & 4 & 14 & 4 \\
\hline & The diversity of visitors negatively affects real & No. & 4 & 26 & 3 & 16 & 1 \\
\hline & estate prices. & Perc. & 8 & 52 & 6 & 32 & 2 \\
\hline \multirow{4}{*}{ 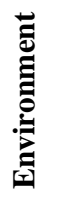 } & The noise of recreational area negatively affects & No. & 15 & 21 & 7 & 5 & 2 \\
\hline & real estate prices & Perc. & 30 & 42 & 14 & 10 & 4 \\
\hline & Water quality and air negatively affect the prices & No. & 3 & 13 & 13 & 16 & 5 \\
\hline & of residential properties & Perc. & 6 & 26 & 26 & 32 & 10 \\
\hline \multirow{4}{*}{ 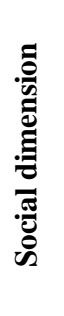 } & The recreational area encourages regular & No. & 2 & 17 & 9 & 17 & 5 \\
\hline & $\begin{array}{l}\text { meetings of the neighborhood residents, which } \\
\text { raising the value of neighboring properties }\end{array}$ & Perc. & 4 & 34 & 18 & 34 & 10 \\
\hline & The recreational area can strengthen social & No. & 8 & 26 & 5 & 9 & 2 \\
\hline & $\begin{array}{l}\text { relations between residents, thus raising the } \\
\text { value of neighboring properties }\end{array}$ & Perc. & 16 & 52 & 10 & 18 & 4 \\
\hline \multirow{4}{*}{ 芯 } & Traffic congestion negatively affects the prices & No. & 8 & 28 & 2 & 9 & 3 \\
\hline & of residential properties & Perc. & 16 & 56 & 4 & 18 & 6 \\
\hline & The urban design of the recreational area & No. & 3 & 16 & 3 & 24 & 4 \\
\hline & $\begin{array}{l}\text { contributes to raising the prices of residential } \\
\text { properties }\end{array}$ & Perc. & 6 & 32 & 6 & 48 & 8 \\
\hline
\end{tabular}

Source: Survey by the authors.

\section{Conclusions}

The result of this paper will divided into two section which is the positive impact of the recreational area that make the property value higher or the negative impact that make the lower value of property.

[1] Positive impact: after finalizing the questionnaire result it shows that there are two factors that are the responsible for making the property value higher which is some of environment and social dimension factors.

[2] Negative impact: As shown on the result the security and urban factors were the negative impact.

The results showed that Al-Hamra neighborhood is considered the highest in land price compared to neighboring areas. The average price of land in the Hamra district is $\$ 826$ per square meter. Land price of residential neighborhoods near Al-Hamra district is declining at an average rate 10\%-39\%. The interviews with the real estate offices indicated that the presence of recreational area has revived the value of neighboring properties. There is a variation in land prices within Al-Hamra district. Land prices in the urban communities near the recreational area are the highest where the average land price in community No.1 is $\$ 933$ per square meter. On the contrary, the average land price in community No.4 is $\$ 720$ per square meter with a decrease of $23 \%$. However, the survey indicated many negative impacts resulting from the recreational area such as traffic congestion, noise, and security. Finlay, this result helps real estate developers improve the quality of life in the residential environment in order to preserve the value of residential properties within Saudi Vision 2030.

Based on the findings of the study the following recommendations were drawn to enhance the positive effects of recreational areas on the residential environment:

1) The development of recreational areas should include an analysis of project impacts to control economic, social and environmental impacts. 
2) Developing regulations and design standards for recreational areas to control the negative effects on neighboring residential properties. These standards include the provision of adequate parking, entrances, green areas, buffer zone, and pedestrian paths separated from the movement of vehicles.

3) Developing criteria for classification of recreational areas to ensure the suitability of the type of activity, density, distance with adjacent residential area.

4) Controlling of working hours and absorptive capacity in accordance with current parking spaces, roads and services.

5) The main entrances of recreational areas should be on main roads away from residential communities to prevent congestion or passive traffic.

6) Recreational areas should be connected with public transport or metro lines as much as possible to reduce the volume of traffic and noise.

7) The planning of recreational areas should be based on a comprehensive analysis of the potential of the site, transport network and land use to ensure that the proposed area is consistent with the characteristics of the site.

8) Supporting community participation in the planning, development, follow-up and evaluation of recreational project through district councils, electronic platforms, surveys, and interviews to address the needs of residents.

9) Evaluating residential satisfaction for recreational projects to improve quality of life in residential neighborhoods and maintain the real estate value of adjacent properties.

\section{Acknowledgements}

The authors extend their appreciation to the Saudi Housing Research Unit at the College of Architecture \& Planning, King Saud University for supporting this research.

\section{References}

Aliyu, A. A., Bello, M. U., AdamuI, H., \& Musa, B. (2016). PARKS/OPEN SPACE AND RESIDENTIAL PROPERTY VALUE: A LITERATURE SURVEY TO ASCERTAIN THEIR MUTUAL RELATIONSHIP. Proceedings/Abstracts \& Programmes of the Academic Conference on Transformation Assessment. Kano: Kano State University of Science and Technology.

Al-Otaibi, O. M., \& Alzamil, W. S. (2019). The Impact of Property Management on the Value of Residential Product in Saudi Arabia. Urban Studies and Public Administration, 2(2), 99-113. https://doi.org/10.22158/uspa.v2n2p99

Al-Qaadi, A., Al-Jarallah, A., \& Al-Diwifi, A. (2004). Factors Affecting Different Rental of Residential Units in Khobar City. King Saud University Journal, 159-175.

Al-Saad, B. (2014). The Reality of Designing and Planning Public Yards as Well as Community Centers at the Residential Districts in KSA. Journal of King Saud University, Architecture and Planning, 87-114.

Alzamil, W. (2016). Evaluation of Affordable Housing and Subsidy Programs in Saudi Arabia. Saarbrücken: LAP LAMBERT Academic Publishing.

Anderson, S. T. (2001). The Effect of Open Space on Residential Property Values in St. Paul, MN. Minneapolis: Macalester College.

Bahamam, A. (2018). Housing in the vision of Saudi Arabia 2030. Journal of Architecture and Planning JAP, $301-314$.

Bolitzer, B., \& Netusil, N. (2000). The impact of open spaces on property values in Portland, Oregon. Journal of Environmental Management, 59(3), 185-193. https://doi.org/10.1006/jema.2000.0351

Clave, S. A. (2007). The Global Theme Park Industry. London: CABI. https://doi.org/10.1079/9781845932084.0000

Crompton, J. L. (2017). The Impact of Parks on Property Values: A Review of the Empirical Evidence. Journal of Leisure Research, 1-31.

Espey, M., \& Owusu-Edusei, K. (2001). Neighborhood Parks and Residential Property Values in Greenville, South Carolina. Journal of Agricultural and Applied Economics, 33(3), 487-492. https://doi.org/10.1017/S1074070800020952

Hailegiorgis, Y. G. (2017). Recreational Parks: Practices and Challenges in Hawassa City. Journal of Tourism \& Hospitality, 6(3), 1-7. https://doi.org/10.4172/2167-0269.1000284

King County's Open Space System. (2004). Parks, Trails, Natural Areas, and Working Resource Lands. King County.

Ministry of Economy and Planning. (2015). Summary of the Tenth Development Plan. Riyadh: Ministry of Economy and Planning.

Ministry of Justice. (2019). The average real estate prices in the neighborhood within a year. Retrieved from 
https://www.moj.gov.sa/ar/opendata/bi/birealestate/Dashboards/100_kpiDistrict/103_Yearly/kpi103_02.aspx

Mitković, P., \& Bogdanović, I. (2004). OPEN AND RECREATIONAL SPACES AS THE PARAMETERS OF THE DWELLING QUALITY. FACTA UNIVERSITATIS: Architecture and Civil Engineering, 3(1), 79-97. https://doi.org/10.2298/FUACE0401079M

MOMRA. (2017). RIYADH CITY REVIEW REPORT. Riyadh: Ministry of Municipal and Rural Affairs.

MOMRA. (2018). National Strategy Policies 2030. Riyadh: Ministry of Municipal and Rural Affairs.

National Transformation Program. (2018). NTP Delivery Plan. Riyadh: National Transformation Program.

Pigram, J. (1983). Outdoor recreation and resource management. Beckenham: Croom Helm Ltd.

Public Investment Fund Program. (2018). Public Investment Fund Program. Riyadh: Public Investment Fund Program.

Vision of the Kingdom 2030. (2016). National Transition Program 2020. Riyadh: Vision of the Kingdom 2030.

\section{Copyrights}

Copyright for this article is retained by the author(s), with first publication rights granted to the journal.

This is an open-access article distributed under the terms and conditions of the Creative Commons Attribution license which permits unrestricted use, distribution, and reproduction in any medium, provided the original work is properly cited. 